\title{
ATONEMENT THEORY REVISITED: CALVIN, BEZA, AND AMYRAUT ON THE EXTENT OF THE ATONEMENT
}

\author{
MATTHEW S. HARDING* \\ Southwestern Baptist Theological Seminary, Fort Worth
}

\begin{abstract}
Throughout the bulk of the Reformed Tradition's history within both Europe and the United States, most scholars have dismissed pastor and theologian Moïse Amyraut as a seventeenth century French heretic whose actions and theology led to the demise of the Huguenots in France. However, upon further introspection into Amyraut's claims as being closer to Calvin (soteriologically) than his Genevan successors, one finds uncanny parallels in the scriptural commentaries and biblical insight into the expiation of Christ between Calvin and Amyraut. By comparing key scriptural passages concerning the atonement, this article demonstrates that Reformed theologian Moïse Amyraut in fact propagated a universal atonement theory which parallels Calvin's, both men ascribing to biblical faithfulness, a (humanistic) theological method, and similar hermeneutic. As such, both Calvin and Amyraut scripturally contend that God desires and provided the means for the salvation of the whole world. Further, the article demonstrates that Calvin's successor, Theodore de Beza, could not in fact make the same claims as Amyraut, this article demonstrating that Beza went beyond Calvin's scriptural approach to Christ's expiation. Therefore, this article supports a more centrist approach from within and outside the Reformed tradition by demonstrating that Calvin and Amyraut concentrically held to God's gracious provision in Christ for the saving of the whole world, for those who would believe in Christ for salvation.
\end{abstract}

KEY WORDS: Amyraut, Calvin, Atonement Theory, Expiation, Beza

\section{Introduction}

The question of the extent of Christ's atonement in John Calvin's theology, whether he embraced a universalist or particularist understanding, continues to be a perennial debate within contemporary historical theology. Closely linked, the question whether the tradition that bears Calvin's name today within Reformed theology is the harmless by-product of natural progression and development from Calvin's seminal thoughts or a gross misrepresentation of a philosophical system that has clearly departed from Calvin's theological method, also continues to be contested within evangelical academia. The late Brian G. Armstrong, who in his own right

* Teacher and pastor, MATTHEW S. HARDING is pursuing his PhD in Historical Theology from Southwestern Baptist Theological Seminary, Fort Worth, TX, and holds a DMin in Church Leadership. 
reignited the debate in the 1960s concerning the possible departure of the Reformed tradition from Calvin's theology, essentially pleads in his work, Calvinism and the Amyraut Heresy, for more aggressive Calvin research into the claims and theology of seventeenth century humanist, Moïse Amyraut, who claimed to represent Calvin's purest theology as opposed to the new orthodox tradition. ${ }^{1}$ In his penultimate scholarly endeavor, Armstrong contends that Amyraut actually represented the closest view of Calvin theologically in terms of the extent of the atonement, though the Amyraldian thesis has been dampened and discredited among successive centuries of Reformed thought.

Conversely, in his own historical analysis, The Extent of the Atonement, G. Michael Thomas traces the thought and expansion of Reformed theology as it specifically concerns various treatments of the extent of the atonement beginning with John Calvin in sixteenth century Geneva up to the Consensus (1675) in later seventeenth century France. Engaging in the modern "Calvin and the Calvinists" debate, Thomas undertook his historical investigation of Reformed theological views toward the atonement due to the research challenge posited by Armstrong for more scholarly inquiry into this untapped historical arena. ${ }^{2}$ Partisanly, Thomas concludes in view of the various interpretations of scholastic atonement theories post Calvin that the scholastic movement within the Reformed tradition only demonstrated a

In Armstrong's main text, he worked off the initial thesis by Basil Hall (1965) that Orthodox Reformed Theology of the 18th century to present had indeed departed from the more faithful understanding of Calvin's soteriology, especially concerning the nature of the atonement. Hall understood that Theodore De Beza specifically initiated the departure from Calvin concerning his emphasis on scholastic methodology as seen in his Tabula. See Basil Hall, "Calvin Against the Calvinists”, John Calvin, ed. by Gervase Duffield (Appleford: Sutton Courtnay Press, 1966), 27. Armstrong states, "Because Amyraut's theology has not until now, I believe, been properly understood. I have thought it expedient to make an exposition of that theology the main interest of this book. I believe that once this theology is properly interpreted a study devoted to a comparison between the theologies of Amyraut on one hand, and of the orthodox on the other, could be a fruitful and fascinating undertaking". B. Armstrong, Calvinism and the Amyraut Heresy (Eugene, OR: Wipf \& Stock, 1969), 265. For the purpose of this paper, this author will retain the nuanced definitions of "Orthodox", "Orthodox Calvinism", and "scholasticism" as employed in Armstrong's thesis, namely that international orthodox Calvinism represented a strong theological and methodological position which was supported by intrinsic reasoning, Aristotelian philosophy, systematization, and deductionary hypotheses all which culminated in rampant speculative conclusions concerning the nature and work of God. See Armstrong, xix. Though contested by Frame, McGeown, Muller et al, and still believing these definitions to be tenable, this paper will argue in one specific loci (the nature of the atonement), that Amyraut both claimed and demonstrated that in both methodology (humanism) and in content, that he was closer to Calvin than Beza and the successive scholastic Orthodox tradition.

2 See Thomas' words as to his reason for this work in the Introduction, G. Michael Thomas, The Extent of the Atonement: A Dilemma for Reformed Theology from Calvin to the Consensus (Bletchley, UK: Paternoster, 1997), 3.

PERICHORESIS $11.1(2013)$ 
natural progression and logical expansion of Calvin's own views of the atonement, and did not represent any stark departure from Calvin theologically.

In short, however, both scholars demonstrated that more work needs to be done in the field to advance more nuanced perspectives of Reformed soteriological thought in order to bring greater perspicuity to the debate. Specifically, both Armstrong and Thomas present that Amyraut's multifaceted theological writings and treatises warrant modern attention, such as Amyraut's claim that his own atonement theory is closer to Calvin than the Reformed scholastic contemporaries of his time. It is to this subject particularly-a comparative study between the extent of the atonement in Calvin, Beza, and Amyraut—which this paper will concentrate.

Therefore, employing an in-depth examination and comparison of Calvin's, Beza's, and Amyraut's atonement theories respectively, this paper will demonstrate that Amyraut is justified in his assertion that his biblical and theological perspective of the extent of the atonement is closer to Calvin's than the scholastic traditional representation of the atonement, championed by Beza. Further, by inference of Amyraut's claims, this paper will re-affirm Armstrong's position that the scholastic movement and methodology within the later orthodox Reformed tradition, in fact, represent a true departure from Calvin's soteriology in respect to a universal versus limited atonement in Christ. ${ }^{3}$ The methodological approach by which this paper will analyze the respective atonement theories will include comparable analysis of each theologian's comments and interpretation of a few selected atonement-related texts of Scripture as compared with Calvin's.

In response to Jonathan Rainbow's 1990 assertion that an analysis and comparison of this sort, i.e. using proof texts within Calvin et al. is "seriously flawed", this author intends to demonstrate that though proof texting may not resolve the issue overall, but each of Calvin's statements in part along with his predecessors in their appropriate contexts comprise the greater picture of relevant themes within each Reformer's theology. Thus, where Rainbow states, "Conspicuous by its absence so far is any systematic treatment of Calvin's thought on the extent of redemption from the inside of his whole theology, in relationship to its dominant themes, including an analysis of both the universalistic statements and those that qualify them", 8, perhaps he is forgetting that he too must look at the parts to discover the whole, or at least verify that the parts of any system such as Calvin's need consistency within the greater framework of a workable and selfattesting theology. Thus, within this study, this author can demonstrate that given the same framework, such as an examination of identical particular verses within the commentaries of Calvin, Beza, and Amyraut—one should be able to analyze their respective insights and draw plausible conclusions as toward the leanings of each Reformer, also comparing them one to another to determine similarities and disparities. Though proof texting may not be the only means whereby to examine the greater complexities of the dominant themes within a respective "systematic" theology, unlike Rainbow, one should not be so quick to dismiss the apparent and obvious insights of intellectuals given in plain form such as commentaries or treatises, allowing the collective parts to speak for themselves as they form a greater whole. In any case, within historical-literary contextual analysis, even unbiased observers should be able to recount similarity and disparity without impugning themselves or the author they seek to understand. Cf. J. Rainbow, The Will of God and the Cross (Eugene, OR: Pickwick, 1990), 8. See, 783 in "Appendix A" of Curt Daniel's Hypercalvinism and John Gill (University of Edinburgh, 1983).

PERICHORESIS $11.1(2013)$ 


\section{John Calvin's Teaching on the Atonement of Christ}

The analysis of John Calvin's perspective and teaching concerning the nature of the atonement is without question anachronistic as it relates to building a case whether Calvin held or would have defended a universal rather than limited or particular atonement in Christ. However, in light of both Beza's and Amyraut's claims to have been closer or more in line with Calvin's soteriology, one can pursue a compelling analysis of what all three men taught, and then attempt an informed hypothesis based on prima fasciae evidence which will either affirm Beza or Amyraut as writing and teaching soteriologically closer to Calvin than the other. Of course, the reality exists that both were erroneous and that neither Beza nor Amyraut could claim with any affinity, a theological approximation to Calvin-since Calvin stands alone as the premiere reformed theologian of his day.

However, in spite of the ongoing debate which centers on whether Calvin was a universal or limited atonement proponent, Calvin did write and express his theological thoughts on the subject of the atonement, which universalists and particularists alike have claimed for their camp. In the following brief section, this author will delineate a few representative texts which indicate that Calvin, in contradistinction to particularists' interpretation, openly embraced biblical, universal language as pertaining to the nature of Christ's atonement and genuine free offer of salvation. ${ }^{4}$ More so, within the nature of the contexts in which these "Calvinisms" are plucked, one can find enthusiastic evidence in Calvin for a plain argument that Christ died openly for all men and for all time, thus, opening the door for ongoing discussions as to why Calvin would even offer such rhetoric if he were staunchly convinced that Christ died for the elect only, as Bezian proponents argue. Thus, within the scope of Calvin's life writings, his treatises, letters, commentaries, sermons, and his beloved Institutes, the following are the most explicit of Calvin's universal language texts, within appropriately relevant contexts, on the subject of the nature of Christ's atonement. ${ }^{5}$

This author is aware that in spite of the current slurry of opinions within both atonement camps, that the Reformed tradition adherents agree that even where Calvin implies universal language as could be interpreted to be imported to the universal atonement camp and evidence that Calvin held to a genuine free offer to all men of Christ's saving gift, that those within the Reformed camp also hold that what Calvin recognizes as a free offer applies only to God's revealed will and explicitly not to His hidden and absolute will-the hidden will which ultimately determines who would or even could within the elect accept the free offer for salvation.

$5 \quad$ Throughout this entire undertaking, this author is cognizant to heed the admonition of Curt Daniel who states, "We have continually been made aware of the intricacy and importance of the subject and the vast amount of instances in which Calvin dealt with the subject compels us to call for a re-assessment of Calvin's position in the light of the evidence itself apart from the temptation to make hasty assessments which would reinforce one's own particular theological persuasion”. Curt Daniel, Hypercalvinism and John Gill (Unpublished Dissertation, Edinburgh, 1983), 777.

PERICHORESIS $11.1(2013)$ 
John Calvin's Universal Language Concerning the Redemption of Mankind

The subject of John Calvin's writings and theological ideals concerning the nature of Christ's atonement is well documented, comprising several books, articles, and dissertations - the sole purpose of which are to demonstrate consistent themes and larger patterns of thought in Calvin's prolific writings by which theologians attempt to taxonomize Calvin's thoughts into formal structures or systems. ${ }^{6}$ In the following texts by Calvin, this author has chosen a small and representative number of substantive quotes and comments from Calvin concerning his understanding and dealings with scriptural passages which imply universal language and which contain universal atonement themes. The following passages need not be significant in and of themselves, but rather these verses will denote an ample foundation for establishing that Calvin not only understood the Bible to speak clearly on universal atonement passages, but that he allowed the biblical texts to speak plainly for themselves without any aid of the interpreter. Further, these few texts will also serve to establish a referent (control group) from which one can adequately compare both Beza and Amyraut and their respective interactions with these texts in the next two sections, as both theologians in their day had ample opportunity to read and absorb Calvin's thoughts on the subject of predestination and the nature of the atonement.

Perhaps Calvin's most infamous statements concerning the nature of the atonement derive from his commentaries where he purports to deal both thoroughly and briefly with the main texts of Scripture. In Calvin's comments on the well-known verses, John 3:15-16, Calvin carefully explains, the Apostle "has employed the universal term 'whosoever', both to invite all indiscriminately to partake of life, and to cut off every excuse from unbelievers. Such is the import of the term "world'." Calvin continues, "For though nothing will be found in the world that is worthy of the favor of God, yet He shows Himself to be reconciled to the whole world, when He invites all men without exception to the faith of Christ, which is nothing else than an entrance into life". ${ }^{8}$ In Calvin's commentary on John 3:17, "not...to condemn the world; but that through him the world might be saved", Calvin further comments on the significance of the meaning of "world" stating, "The word "world' is again repeated, that no man may think of himself wholly excluded... showing that

For example, R. T. Kendall, Calvin and English Calvinism (Milton Keyes, UK: Paternoster, 1979) contains two sections on Calvin's perspective of the nature of the atonement. Also, Robert Peterson, Sr., Calvin and the Atonement (Geanies House, Scotland: Mentor, 1999); and Charles M. Bell, "Calvin and the Extent of the Atonement" The Evangelical Quarterly 55 (1983): 115-123; Curt Daniel, "Appendix A" in his unpublished dissertation, et al.

7 John Calvin, "Commentary on the Gospel According to John”, Calvin's Commentaries, vol. 17, trans. by W. Pringle (Grand Rapids: Baker, 2009), 125.

8 Ibid., 132. 
He here includes all men in the word 'world', instead of restricting it to comprise the elect alone". ${ }^{9}$

Concerning the most critical of atonement passages to be found in Scripture, namely 1 John 2:2, even Reformed theologian, A. H. Strong, acquiesces that Calvin's tone is quite universalist. Quoting Calvin's commentary to The First Epistle of John, Strong recites Calvin's deliberate words:

Christ suffered for the sins of the whole world and in the goodness of God is offered unto all men without distinction; His blood being shed not for a part of the world only but for the whole human race. For although in the world nothing is found worthy of the favor of God yet He holds out the propitiation to the whole world, since without exception $\mathrm{He}$ summons all to the faith of Christ which is nothing else than the door unto hope. ${ }^{10}$

Here, Calvin gives an unadulterated perspective that the Bible teaches a universal expiation whereby Christ died and suffered for the sins of the whole world, not just for the elect. As such, contrary to orthodox Reformed theology, Calvin plainly states that Christ's blood was shed (given) not for part of the world, but the whole of the human race. Additionally, Calvin comments on the text of Romans 5:18

where he states that God makes his favor common to all, because it is propounded to all, and not because it is in reality extended [i.e. through their hearing about it]; for though Christ suffered for the sins of the whole world, and is offered through God's benignity indiscriminately to all, yet all do not receive him. ${ }^{11}$

Calvin again does not shy from stating what he understands is the plain reading of the text, namely that Christ is both offered to the world for salvation because God intended for Christ to expiate the sins of the whole world. By extension, Calvin exclaims that the church is to preach the gospel indiscriminately to all, yet knowing that all or even most will not receive it. Notably, Calvin forces no eisogetical conditions upon Scripture and allows the text to speak plainly for itself; Calvin does, however, accentuate the reality that God's intention (or design) will always match God's efficacious work, demonstrating that Calvin held to a balanced view of predestination whereby God does what He intends regardless whether it is revealed or hidden. In these texts, the observer notices that Calvin opens himself up to other

9 John Calvin, Commentary on John's Gospel, trans. by William Pringle (Grand Rapids: Eerdmans, 1949), 75. Italics emphasized by the author. Unless otherwise indicated, all scripture quotations will be taken from the New American Standard Bible, 1995 Update, Lockman Foundation.

10 John Calvin, "Commentaries on the First Epistle to John”, Calvin's Commentaries, vol. 22, trans. by W. Pringle (Grand Rapids: Baker, 2009), 172 as cited in A. H. Strong, Systematic Theology (Valley Forge, PA: Judson Press, 1993), 778.

11 John Calvin, "Commentaries on the Epistle to the Romans", Calvin's Commentaries, vol. 19, trans. by W. Pringle (Grand Rapids: Baker, 2009), 211.

PERICHORESIS $11.1(2013)$ 
possibilities concerning the nature and design of the atonement more so than the later orthodox Reformed tradition does or would contest concerning Calvin.

Another straightforward example where Calvin allows the Scripture to dictate a strong universalist ideal concerning the nature of the atonement is found in Colossians 1:14, which states "in whom we have redemption, the forgiveness of sins". On this verse, Calvin asserts, "by the sacrifice of his death all the sins of the world have been expiated". ${ }^{12}$ Calvin repeats again this claim in John 17:1, stating "for [by Christ's death] we know that by the expiation of sins, the world has been reconciled to God". ${ }^{13}$ Calvin corroborates this text with Gospel witnesses where he elucidates that in both Matthew 26:28 and Mark 14:24, which concludes by the "blood...shed for many for the remission of sins", that "by the word 'many', he means not a part of the world only, but the whole human race". ${ }^{14}$ Further, Calvin clarifies this universal sentiment in his Institutes claiming, "The salvation brought by Christ is common to the whole human race, inasmuch as Christ, the author of salvation, is descended from Adam, the common father of us all". ${ }^{15}$

Perhaps the most substantive passage which helps the modern reader have a keen insight into the mind of Calvin as he interprets Scripture for his congregants is reflected in his commentary on John 3:16, which is corroborated within a sermon on Isaiah 53. In spite of its length, the substance of his quote alone represents a multitude of other texts with similar vein. Thus, this one representative quote demonstrates Calvin's consistent tendency to allow the text to speak for itself as part of his ongoing hermeneutic; more important, however, this text underscores Calvin's willingness to consider the universal language of both Testaments as normative when appropriating atonement theory texts. Calvin states:

Yet I approve of the common reading, that He alone bore the punishment of many, because the guilt of the whole world was laid upon Him. It is evident from other passages... that "many" sometimes denotes "all"... That, then, is how our Lord Jesus bore the sins and iniquities of many. But in fact, this word "many" is often as good as equivalent to "all". And indeed, our Lord Jesus was offered to all the world. For it is not speaking of three or four when it says: "God so loved the world, that He spared not His only Son". (John 3:16). But yet we must notice what the Evangelist adds in this passage: "That whosoever believes in Him shall not perish but obtain eternal life". Our Lord Jesus suffered for all and there is neither great nor small who is not inexcusable today, for we can obtain

12 Calvin, Commentary on Philippians, (Grand Rapids: Eerdmans, 1949), 148.

Calvin, John, 161.

Calvin, Commentaries on the Harmony of the Gospels, vol. 2 (Grand Rapids: Eerdmans, 1949), 214.

John Calvin, Institutes of the Christian Religion, ed. by John T. McNeill, trans. by Ford Lewis Battles, vol. 1, The Library of Christian Classics 20-21 (Philadelphia: Westminster, 1960), 2.13.3. Institutio Christianae Religionis, vol. 3 of Joannis Calvini Opera Selecta, ed. by P. Barth and G. Niesel (Munich: Kaiser, 1926-36).

PERICHORESIS 11.1 (2013) 
salvation in Him... Let us not fear to come to Him in great numbers, and each one of us bring his neighbors, seeing that He is sufficient to save us all. ${ }^{16}$

This text, then, can represent a summation of Calvin's thoughts toward the nature of the atonement as being universal in design. From these few listed texts, out of possible hundreds within Calvin's proliferation, a representative base can be established by which to compare the tone and substance of both Beza's and Amyraut's interaction with Scripture and Calvin. Similarly, one should note the relative ease (or lack of) that either Beza or Amyraut possess in interacting with both the biblical text and Calvin's perspective concerning understated universal language related to the nature of the atonement. Will Beza or Amyraut accommodate their respective theologies as informed by Scripture as apparently Calvin does? Or will these texts and theological interpretations demonstrate that the biblical text must be accommodated to fit each respective theological system? Thus, upon examination of a few scriptural claims and the subsequent interpretation by Beza and Amyraut, with respect to Calvin, one should be able to determine if Amyraut's claims as being closer to Calvin soteriologically [in terms of the atonement] are justified.

\section{Theodore Beza's Limited Atonement Contention}

Theodore Beza needs little introduction within Reformed circles or among interested parties to the debates concerning classic Calvinism. As Calvin's direct successor, hand-picked by Calvin himself, the father of francophone Reformed theology assigned to Beza the highest distinction as both pastor and theologian within the Reformed world. As recent scholarship has demonstrated differences or variances between Calvin and Beza's theology, many scholars maintain that Beza naturally and innocuously developed Calvin's thoughts into a leading Reformed tradition, consistent with any natural progression of ideas throughout time. ${ }^{17}$ In contradistinction to Calvin's universal language toward the redemption of men, Beza understands and expands Calvin's theological insights through the logical outworking of the decretal system. ${ }^{18}$ Beza centers his theological paradigm on the nature of God, His unchangeable and ineffable essence within God's being. As such, Beza contends (London: James Clarke \& Co, 2002), 136.

17 The following scholars hold that Beza simply developed Calvinism into the naturally ordered state and logical progression of ideals consistent with other faith traditions which have developed over time into more formalized theological systems.

18 For an in-depth treatment of Beza's doctrine of predestination and soteriological framework based on his Tabula, see John S. Bray, Theodore Beza's Doctrine of Predestination (Nieuwkoop: B. De Graaf, 1975), particularly chapter IV and the summary, $137 \mathrm{ff}$. Cf. Scott Manetsch, Theodore Beza and the Quest for Peace in France, 1572-1598 (Leiden: Brill, 2000); Jeffrey Mallins, Faith, Reason, and Revelation in Theodore Beza: 1519-1605 (Oxford: Oxford Theological Monographs, 2003); Paul Geisendorf, Théodore de Bèze (Geneva: Julien, 1967); and R. Letham, "Theodore Beza: A Reassessment", SJT 40 (1987): 25-40. 
that the issues of salvation rest in God's sovereign and providential, pre-temporal planning of the universe. Thus, for Beza, a supralapsarian predestinational decree becomes the foundation for God's choosing and reprobating human souls before the act of creation materializes. More so, in Beza's soteriological scheme, Christ's atoning work is subjugated to God's decree, thereby assuming Christ's atonement on the cross would yield causally to the predetermined intention of God. Therefore, according to Beza's system, only the elect were in mind for salvation from the initial divine decree. Concurrently, in the Bezian system, Christ's expiatory work is submissive to the divine decrees and actively mirrors God's intention to redeem only a certain few from eternity past, thereby enabling the logical deduction that Christ's atonement was effectual only for the elect-only for those preordained to salvation. $^{19}$

W. Robert Godfrey summarizes Beza's soteriological scheme stating, "the benefit of the atonement properly belongs to the elect alone. Beza's concern was to stress the efficacious nature of the atonement. Salvation was not made possible in Christ; it was made actual for the elect of God". ${ }^{20}$ Syllogistically consistent, then, according to Beza, "by positing the Redeemer for the elect only, makes His death efficacious in itself. Since God will not demand double payment, those for whom Christ died must be saved. Had Christ died for all, according to the value Beza places on Christ's death, all would be saved". ${ }^{21}$

Similarly with the analysis of Calvin's statements concerning his use of universal language concerning redemption, the following excerpts by Beza demonstrate his soteriological perspective, holding in toto that Christ's death and atonement were

Beza maintains, "The one and only sacrifice of Christ once made, is sufficient for the abolishing of all the sins of all the faithful". T. Beza, Cours sur Les Epîtres aux Romains et aux Hebrieux 156466; d'après Les notes de Marcus Widler, ed. by P. Fraenkel and L. Perrotet (Geneva, NP. 1988), 406. Further, Beza states, "It is impious and blasphemous... to say that those whose sins have been expiated through the death of Christ, or for whom Christ has satisfied, can be condemned". T. Beze, Ad Acta Colloquii Montisbelgardensis Tubingae Edita Theodori Bezae Responsio pars altera (Geneva, 1588), 215.

20 W. Robert Godfrey, "Reformed Thought on the Extent of the Atonement to 1618", Westminster Theological Journal 37:2 (1974): 134.

21 R. T. Kendall, Calvin and English Calvinism to 1649 (Milton Keyes, UK: Paternoster, 1997), 32. Beza's logical deductionism continues within the Reformed Tradition to present. Sinclair Ferguson and J. I. Packer, two prominent Reformed theologians state: "Therefore, Christ's purpose in incarnation and atonement was to save his people from their sins. His death was not intended to atone for every human being; for then either he would have failed, or the road would lead to universalism, uniformly rejected as unbiblical. [Contrary to Amyraldianism], nor did the cross provisionally atone for all while intrinsically accomplishing nothing, leaving atonement in suspense, contingent upon believing appropriation of Christ. Rather, Christ made effective atonement for the sins of all his people. Sinclair B. Ferguson and J. I. Packer, New Dictionary of Theology (Downers Grove, IL: InterVarsity Press, 2000), 570. Beza adds, "God does not will all men to be saved by an absolute will. For thus all would certainly be saved... but by a restricted will in Christ, out of whom he wills no-one to be saved". T. Beze, Ad Acta Colloquii Montisbelgardensis Tubingae Edita Theodori Bezae Responsio pars altera (Geneva, 1588), 7.

PERICHORESIS 11.1 (2013) 
intended and effectual only for the elect. Demonstrating the framework of Beza's soteriological mindset, Beza states, "predestination is God's eternal and unchangeable ordinance, which came before all of the causes of salvation and damnation, and by which God has determined to glorify himself-in some men by saving them through his simple grace in Christ and in other men by damning them through rightful justice in Adam and in themselves. ${ }^{22}$ In short, Beza's philosophical system subsists on the reality that "Christ died only for the elect". ${ }^{23}$

Perhaps the clearest disparity between Calvin's intention and use of universal language in redemption as compared with Beza, is seen in their respective treatments of biblical hermeneutics, such as their interpretation of controversial passages found in the Gospel of John, 1 Timothy, 2 Peter, and 1 John. In each of these passages, Beza reckons that all verbage which may imply a universal intent or divine appeal for the salvation of the world is to be interpreted through the lens of logical deductionism, whereby the biblical terms "all", "whole", and "world" must be qualified and delimited. By comparing Calvin's use of the same passages with Beza, Bray concludes, "Calvin stayed with what was at least the apparent universal emphasis of the passages, whereas Beza became involved in a controverted, polemical exegesis, the main thrust of which was to argue for a limited atonement". ${ }^{24}$

For example, in 2 Peter 3:9, Calvin allows the plain reading of the text concerning that God is "not willing that any should perish" to declare "so wonderful is his love towards mankind, that he would have them all to be saved, and is of His own self prepared to bestow salvation on the lost" ${ }^{25}$ The emphasis which Calvin holds for this passage is that "in the like manner God does not hasten the end of the world, in order to give to all time to repent". ${ }^{26}$ Here Calvin speaks of the benevolent heart of God and His patience toward lost man, enabling ample time for man to hear the gospel and repent. Calvin here highlights God's magnificent love towards mankind such that He would have them all to be saved. More so, Calvin also underscores the lengths to which God has gone to accomplish the salvation for all men, namely that God "bestows salvation on the lost" through the gift of His Son and has elongated

Theodore Beza, Quaestionum et Responsionum Christianarum Pars Altera, Quae Est de Sacramentis (Geneva, 1576), 116. Cf. Theodore Beza, A Booke of Christian Questions and Answers: Wherein are Set Forth the Chief Points of the Christian Religion, trans. by Arthur Golding (London: W. How, 1574).

23 Theodore Beza, Tractiones Theologicae, vol. 1. (Geneva, 1570-1582), 171. Cf. 183 and Quaestiones, 120-121; cited in G. Bray, Theodore Beza's Doctrine of Predestination (Nieuwkoop: b. De Graaf, 1975), 112.

24 Bray, Theodore Beza, 112. David C. Steinmetz adds, "Beza... allowed the doctrine of election to qualify the doctrine of the atonement. According to Beza, Christ died only for the elect. While Calvin may have entertained this idea, only Beza flatly stated it". David C. Steinmetz, Reformers in the Wings (Oxford: Oxford University Press, 2001), 118.

25 John Calvin, "Commentaries on the Second Epistle to Peter", Calvin's Commentaries, vol. 22, trans. by W. Pringle (Grand Rapids: Baker, 2009), 419.

$26 \quad$ Ibid., 419. Italics emphasized by the author. 
time sufficient for the maximum number of the lost to be saved and engrafted into the church. Conversely, in this same passage, Beza only emphasizes the means by which the elect can be saved.

Beza comments, "he speaks not here of the secret and eternal counsel of God, whereby He elects whom it pleases Him, but of the preaching of the gospel whereby all are called and (biddeth to the banket) [invited to the banquet]". ${ }^{27}$ Here Beza ignores the contextual emphasis of Peter's admonition, namely that God's timing is perfect and infinitely matches God's gracious and loving heart towards the lost world. Rather than highlight the natural reading of the text, Beza instead irreconcilably relates the desire of God towards the salvation of the lost to the secret decretal will of God to choose only the elect. In this passage, Beza redirects the main thrust of the text from God's patience and desire towards the lost to the practical means by which men hear the gospel, namely the act of preaching. Thus, Beza diverts his readers from the main emphasis of the text which Calvin gladly embraced, Beza demonstrating a refined hermeneutic which deductively syncretizes God's divine decrees, eternal intentionality, and elective purposes with the natural reading and plain meaning of the biblical text. For Beza, this text refers less to the hope for the lostness of mankind as it does the elect of God and His will to save expressly the elect. Yet surprisingly, for Beza, even less does the text relate to God's nature, intentionality, or will for the lost than it relates to the mode of salvation which highlights the church's role of preaching and proclaiming truth.

Further, in reference to the Apostle's John's appeal of God's universal love toward all mankind through the action and effectual provision of His Son as perfect expiation of all sin, Beza understands the message of John 3:16 and 3:17 as explicitly not of the universal desire to save and redeem all men. Rather, in commenting on these texts, Beza redirects his readers to the message of 1 John 4:9 which accentuates the believing church as the sole attention of God's love. In the notes on the passage in 1 John, Beza concludes, "truth it is that God has declared His love in many other things, but herein ["In this appeared the love of God toward us, because God sent His only son into the world, that we might live through Him"-1 John 4:9] has passed up all others". ${ }^{28}$ Beza's emphasis concerning God's love and provision of salvation precludes the "whole world" as stated plainly in John 3:16-17 and only applies God's love to "us" and "we" as the church, the elect of God. Beza emphasizes that the true receivers of God's love are those who have actually received God's gift of salvation in the elect. ${ }^{29}$ Thus, in these passages, Beza holds that God never intends a universal or saving love for the world, but rather, that the Apostle John's (Geneva, 1560), notes on 2 Peter 3:9.

Ibid., 1 John 4:9. Italics emphasized by author.

Referring to correspondent J. Andreae's enquiry about John 3:16, G. Michael Thomas states, "Beza replied that the world God loves is not to be understood universally, but indefinitely, with reference to those who believe in Christ, just as Christ said that he did not pray for the world 
emphasis is better clarified through 1 John 4:9 in that God's love is intended for the elect alone. By logical extension, Beza holds that God's love is best demonstrated in His act to save effectually the elect, the true church being the appropriate recipients of God's love and not a wasteful glance towards the world (lost). Again, Beza eisogetically reads his decretal hermeneutic into the text, predetermining on behalf of God who God meant to show His universal and benevolent love.

Conversely, Calvin plainly states his understanding of the text of John 3:16-17 as referring to God's universal love and desire towards the lost world. Calvin states, "Faith in Christ brings life to all, and that Christ brought life, because the Heavenly Father loves the human race, and wishes that they should not perish" ${ }^{30}$ Instead of limiting the terms of "all" and "world" to those of the elected classes of men within the church, Calvin clearly states that God's love and action was put forth on behalf of all men. Calvin understands John's textual emphasis that the nature of the pericope be a theological and pastoral appeal to the lost world, giving rise to the nature of the infinite love of God and His perfect provision (propitiation) of sin through Christ's death and atonement. In contradistinction to Beza's inherent focus on the elect as the sole recipients of God's salvific actions, Calvin underscores John's universal message that Jesus is the ultimate expression of God's love both in the incarnation and expiation on behalf of the whole world. Calvin states, "And he has employed the universal term whosoever, both to invite all indiscriminately to partake of life, and to cut off every excuse from unbelievers. Such is also the import of the term World, which he shows himself to be reconciled to the whole world, when he invites all men without exception to the faith of Christ". ${ }^{31}$ Calvin's words could hardly be clearer or more distinct in tone and purpose from Beza's, as both men attempted to help their readers and congregants better understand the heart of God toward the world.

Concerning the text John 3:17, Beza distinguishes that "world" does not mean the whole world or all the individuals in the world as the referent of God's love or Christ's work, but that “'world” means not simply Jews, but whosoever should believe in Christ". ${ }^{32}$ For Beza, the concept of the world in any spiritual sense necessitates the whole of the elect. For example, in the text 1 John 2:2, Beza advances that "the whole world" here means "of them which have embraced the Gospel by faith in all ages, degrees, and places for there is no salvation without Christ". ${ }^{33}$ Thus, the

\footnotetext{
but for those given him by his Father. 'The world' in John 3:16 means the elect throughout the world. A will of God to save all individuals cannot be meant, because what God decrees, he also performs, since he cannot be impeded or changed". G. Michael Thomas, The Extent of the Atonement (Milton Keyes, UK: Paternoster, 1997), 56.

30 John Calvin, "Commentary on the Gospel According to John", Calvin's Commentaries, vol. 17, trans. by W. Pringle (Grand Rapids: Baker, 2009), 123.

Ibid., 125.

Theodore Beza, Novum Testamentum, John 3:17.

Ibid., 1 John 2:2.
}

PERICHORESIS $11.1(2013)$ 
consistent decretal framework by which Beza informs his hermeneutical task demands that the elect be comprehended in all salvific forms of God's intent and Christ's actions. For Beza, the text leaves no room for God to have intended or desired any other concept but that only the elect receive the favor, the love, and the work of God. In the Bezian soteriological system, no room is left for the possibility that God would or did limit the atoning effects of salvation by the act or gift of faith. Rather, according to Beza, the work of salvation fixed once for all is an effectual saving act designed for the elect only, necessitating that the elect are the sole intendants, recipients, and benefactors of God's love. For Beza, then, God's love stretched out only for His church, as the church of Christ is the sole arm of redemption in the world.

Last, in reference to 1 Timothy 2:4 and other similar texts, Beza consistently holds that the words "all men" mean merely "Jew and Gentile, poor and rich", stating that it is God "who will reconcile of all nations, people, and sorts to one God". ${ }^{4}$ Even here, where the plain reading of text can dictate a full meaning within proper syntax and context, Beza relies more on speculative reason to determine the meaning of the words "all men", adding consistency to a hermeneutic of decrees and elective bias. Rather than referring to the universal "all" of similar passages, indicating God's provision and possible intention within the action and benefit of salvation, Beza seems to understand a more delimited nature of the word "all", thereby relegating many pericopes of scripture to a hermeneutical limitation which emphasizes God's limited intention and action toward a particular people.

In the very same passage, Calvin otherwise clarifies what he means as he delimits the phrase "all men" from individuals to classes of men and not simply "persons". Calvin's emphasis is not only to uphold the doctrine of predestination, but that the free and genuine offer of salvation is rendered to all peoples and not merely one type, group, or special attachment of peoples. Thus, Calvin states "Since, therefore, God wishes the benefit of his death to be common to all, an insult is offered to him by those who, by their opinion, shut out any person from the hope of salvation". ${ }^{35}$ Calvin, in contradistinction to Beza, uses plain biblical language to underscore the necessity of God's love toward all peoples, emphasizing that God's work of salvation is to be freely offered to all peoples without distinction, because God made provision for all people through the perfect redemption of Christ. Though Calvin and Beza use similar language in this text, their understanding and intention seem to be at odds. For Beza, he repurposes the plain meanings of words in order to limit further the intention and action of grace as consistent with a limited atonement approach. For Calvin here, he seems to employ delimiters on the natural reading of the words

Ibid., 1 Timothy 2:4. Accordingly, Beza states in his Ad Acta, that 1 Timothy 2:4-6 is to be understood "according to all the orthodox fathers, especially Augustine" as meaning "non singulos generum, sed genera singulorum" [not each one singularly, but each of every kind] T. Beze. Ad Acta Colloquii Montisbelgardensis Tubingae Edita Theodori Bezae Responsio pars altera (Geneva, 1588), 211. John Calvin, "Commentaries on the First Epistle to Timothy", Calvin's Commentaries, vol. 21, trans. by W. Pringle (Grand Rapids: Baker, 2009), 56. 
in order to emphasize that God will leave none out of His gracious provision of love and intention that all may hear and receive the gospel message of salvation.

In drawing the apparent contrasts between Calvin and Beza concerning the nature and extent of the atonement, Thomas concludes: "in striving for coherence within a polemical context, Beza eliminated or subdued other apparently contradictory elements in Calvin's thought. Notable among these were the universal saving will and promise of God and the universal aspect of the atonement" ${ }^{36}$ Thus, of the many areas of theological agreement with the Genevan father to his successor, one area of significant disparity between Calvin and Beza concerns the nature of the atonement. Specifically, Calvin remains more open to the idea that the biblical text often implies God's universal desire to save all of mankind, having sent Jesus to die as the perfect expiation on behalf of the whole world. Conversely, Beza, in commenting on several universal language passages in the New Testament leaves little room outside his deductionist hermeneutic to see that God has any desire to save all of mankind or that Jesus was sent on behalf of all the world and its $\sin i n$ toto. Unlike Calvin, Beza concludes that Jesus died indefinitely and effectually for the elect alone, in submission to and accomplishing the decretal intention of God from before the foundation of the world. It is to this contested doctrine, the extent of the atonement, which Amyraut also felt that Beza had logically misappropriated, as he felt Beza was constrained by his own logical system and not the plain testimony of Scripture alone.

\section{Moïse Amyraut's Universal Atonement Prescription}

Moïse Amyraut was a prolific seventeenth century French theologian and pastor who led the Academy of Saumur and who historically influenced national French politics between the Roman Catholic government and its tenuous relationship with French Protestants. Amyraut is infamous for being both Reformed in his theology while simultaneously dividing seventeenth century Reformed loyalties concerning the doctrine of predestination, and by extension, the extent of Christ's atonement. Specifically, Amyraut reacted against the new orthodox Reformed (Bezian and Dortian) logic-oriented tradition, which advanced that Christ died only for the elect, owing to a deductionist decretalism.

At the heart of Amyraut's soteriology lies the conundrum that though the Bible declares that God desires all to be saved, Scripture also evinces that all are not ultimately saved. Therefore, Amyraut, like Calvin before him, sought to find a biblical solution to the apparent quandary, while upholding the sovereignty of God and a high view of Scripture. Thus, building on his professor and mentor's theological framework, John Cameron, Amyraut's doctrine of predestination rests on the dual premises of (1) an historical approach to the work of the Trinity (a non-heterodox economic view of the Trinity), and (2) the reality that God displays two seemingly irreconcilable wills or aspects of His own work; first, Amyraut contended that God

36 Thomas, The Extent of the Atonement, 56.

PERICHORESIS $11.1(2013)$ 
made provision for the salvation of all men through Christ's indiscriminate propitiation (conditioned upon man's belief) and second, that God does still discriminately choose whom He will elect to give saving faith through the work of the Holy Spirit. Amyraut explains that in Scripture God reveals two ways of "willing" something, though seemingly paradoxical. One will simply makes its desire known (as in God's revealed will), while the other type of will effectively provides the necessary means to make its desire actual. ${ }^{37}$

Chronologically, Amyraut sees a distinct work of the Trinity in this saving action, namely that God has designed and intends the salvation of the world based on His love and grace, demonstrated through the universal atonement in Christ Who perfectly accomplishes His Father's will and universal intention. Further, then, the Holy Spirit Who proceeds from both the Father and Son effectively brings life and salvation to the elect, by bestowing the necessary gift of faith upon the predestined. Thus, in short, Amyraut contends that the biblical doctrine of predestination simultaneously exerts that Christ's death was universal, extending to all humanity and covering all sin, while concurrently requiring an electing faith given to only certain men by God's perfect wisdom and love. ${ }^{38}$

Amyraut, though being trained by humanist professors under the auspices of Reformed Orthodox Theology, chose to reject the common understanding of traditional predestination, believing that "Hypothetical Universalism" was supported more faithfully in Scripture. Initially, Amyraut set out to soften the rhetoric and misapprehension of the caustic Reformed ideals of predestination as perceived by Roman Catholics, Arminians, and the lost masses. Thus, for Amyraut, his pursuit of a better explanation of scriptural predestination was successful in that his perspective aligned more favorably: (1) with all the testimony of Scripture, (2) with the teachings of the father of the French Reformed movement, namely John Calvin, ${ }^{39}$

Amyraut, Defense de la Doctrine de Calvin Sur le Sujet de l'Election and Réprobation (Saumur: Isaac Desbordes, 1644), 268.

38 It is here theologically where Amyraut was accosted by his Reformed colleagues Pierre Du Moulin and Frederic Spanheim. Being pejoratively labeled "Hypothetical Universalism", Amyraut contended against Bezian orthodox Reformed theology that Christ's sacrifice was universal in intention and scope, in perfect alignment with God's divine decree and predetermined plan. See Amyraut's main thesis in his "De Gratia Universali", Dissertationes Theologicae Sex (Saumur: Desbordes, 1645), 123, and within his infamous Brief Traitté de la Prédestination et Ses Principales Dépendances (Saumur: Lesnier \& Desbordes, 1634), $77 \mathrm{ff}$.

39 Amyraut is so convinced that his actual understanding of predestination concerning the extent of the atonement is coextensive with Calvin's, that Amyraut published both a pamphlet entitled L'Eschantillon de la Doctrine de Calvin Touchant la Predestination (1658) [trans. A Sample of Calvin's Doctrine of Predestination] and a massive tome entitled La Defense De La Doctrine De Calvin Sur Le Sujet de L'Election et De la Reprobation (1644) as demonstration that Amayraut's soteriology aligned squarely with Calvin's. Brian Armstrong has done the work of demonstrating how Amyraut coalesces his own work with that of Calvin. Armstrong states: "Certainly one of the striking aspects of Amyraut's work is the complete familiarity he shows with Calvin's writings. In his writing he piles quotation upon quotation from Calvin, drawing from a great variety of Calvin's work.

PERICHORESIS $11.1(2013)$ 
(3) with the Canons of Dort, (4) with the opponents of strong Calvinism, namely the Roman Catholic Church and Arminians, and (5) with establishing a wider union with the Lutherans. ${ }^{40}$

Concerning Amyraut's main thesis that God both wills the salvation equally of all men and has made provision to accomplish salvation through Christ's general atonement, Amyraut contends:

Since the misery of men is equal and universal and since the desire that God has had of delivering them by such a great Redeemer proceeds from the compassion which He has for them as His creatures that have fallen into such a great ruin and since they are equally his creatures, the grace of redemption which He has procured and offered to them ought to be equal and universal, provided that they are also found to be equally disposed to receive it. And to this extent there is no difference between them. ${ }^{41}$

Further, as Amyraut properly clarifies the doctrine of predestination, he stresses the universal intention of God as God's best design. Amyraut states,

The sacrifice that He has offered for the propitiation of their offenses has been equally offered for all, and the salvation that he has received from his Father to communicate to men in the sanctification of the Spirit and in the glorification of the body is intended equally for all, provided, I say, that the disposition necessary to receive it is in the same way equal. ${ }^{42}$

There are, for example, more than a dozen quotes from Calvin in the Six Sermons of 1636, some thirty-seven often lengthy quotes in the Eschantillon de La Doctrine de Calvin of 1636, at least 103 extensive passages from Calvin in his Defense de la Doctrine de Calvin of 1644, and frequent references from Calvin in each of the writings in which Amyraut was defending his own position... In the Defense de la Doctrine de Calvin [Amyraut] often switches back and forth from the first to the third person. I have not counted the references in Specimen Animadversionum, but they are probably more numerous than in any writing except the Defense. Brian G. Armstrong, Calvinism and the Amyraut Heresy (Madison: University of Wisconsin Press, 1969), 187. Further, Armstrong notes: "One of the most arresting features of Amyraut's doctrine of predestination is that his opposition to orthodox teaching was made in the name of Calvin and the early reformers, presenting at the same time a decided bias against Beza, Martyr, and Zanchi", 158. "He not only believed that he was true to Calvin when he contended that the doctrine of predestination was legitimate in theology only as an ex post facto explanation of grace, but he also used Calvin to justify and support his own position, 161, cf. Defense, 274-313.

40 These main points are cited by Roger Nicole, Moyse Amyraut and the Controversy on Universal Grace (unpublished Dissertation, Harvard University, 1966), 4. Concerning the controversy of predestination within Amyraut's political setting, Amyraut states his desire to publish a small treatise on predestination in the common lay-oriented vernacular of French expressing, "My intention has solely been to render this doctrine [predestination], which has been esteemed so thorny and difficult, easily understood by all" (Brief Treatise, iii).

41 Moïse Amyraut, Brief Treatise (1634), 38.

42 Ibid., 38. Amyraut is often accused of taking the universal language of Scripture too far as he mentions that Christ's propitiation for all men is fitting and perfect to redeem any, conditioned upon belief-even if a person has never heard the name of Christ. Amyraut, no doubt hearkening to the O. T. Saints' testimonies and Hebrews 11, states, "That is why it is impossible to doubt 
When comparing the same scriptures concerning the extent of the atonement previously analyzed in both Calvin and Beza, Amyraut has much to add from his perspective that a natural reading of these texts reveals God's heart toward the world with both a universal intent and provision, the plain text being unencumbered by any logical deductionism or philosophically-tainted hermeneutic. Concerning the text in 2 Peter 3:9, Amyraut emphatically understands the Apostle as clarifying God's universal heart and intent toward the world's salvation. Amyraut comments,

For although He does not reveal distinctly to all who this Redeemer is by whom they have been saved, such is the providence by which He preserves them, the temporal blessings through which He arouses them and furnishes them continually, and the long-suffering and incredible patience which He exercises toward them, as to be sufficient preaching for them, if they are attentive, to make them understand that there is mercy in his presence for those who resort there in faith and repentance. Accordingly the Apostle taught that "the riches of his goodness, and his patience and of his long suffering lead men to repentance". (Romans 2:4) $)^{43}$

Heartily agreeing with Calvin's own interpretation of 2 Peter 3:9 and the force by which Calvin underscores God's patience and desire of salvation for all mankind, Amyraut states, "The confidence that Calvin had in the goodness of his cause and the candor with which he has proceeded in the interpretation of Scripture have been so great, that he had no qualms about interpreting the words of St. Peter in this manner". ${ }^{4}$

that if in some nation of the world where even the name of Christ is not known, it happened that He [God] recognized someone who, touched by the testimonies of God's mercy which he presents to all men in the administration of all aspects of the universe, was truly converted to him so as to obtain the salvation of his grace, it would only give him delight”. Brief Treatise, 40. However, Amyraut's argument here is not that people around the world are regularly getting saved apart from the knowledge of Christ (via some special revelation), but rather that Christ's death and propitiation are perfect and extends to all humanity. Amyraut appeals to 1 John 2:2, Romans 2:4, and 1 Timothy 2:4:5-6 to demonstrate the efficacy of Christ's expiation on behalf of all men and all sin. More so, Amyraut being a strong Reformed theologian emphatically holds that unless God sends His special grace in the form of a gift of faith through the Person of the Holy Spirit—no man can be saved. "For all those who believe have formerly been in the mercy of God predestined to believe, no one being able to believe except by the gift of God, except by an eternal election and predestination" (Brief Treatise, 83). Thus, Amyraut does hold to limited atonement per se, but not at the cross. Rather, Amyraut limits grace to only those who God chooses to render special grace, saving faith, and the draw of the Holy Spirit, though all men's sins have been perfectly atoned for in Christ.

43 Ibid., 40

44 Amyraut, Defense, 125. Armstrong, displaying Amyraut's apparent bias against orthodox methodology and speculative-driven hermeneutic further notes that Amyraut's comments toward Calvin's commentary "implies that the methodology of [Reformed] orthodoxy destroyed the candor with which one should deal with biblical texts and that orthodoxy manifested an almost neurotic fear that somehow a sacred theological system might crumble if certain interpretations 
Perhaps taking his cue from both Scripture and Calvin, Amyraut's comments on the famous evangelical passage of John 3:16, 17 mirror Calvin's perspective and theological insights. Amyraut echoes Calvin's thoughts stating, "And although these words (John 3:16) seem to go so far as to make this grace of God universal, as proceeding from the love that God has had for the human race, they nevertheless restrict it to those who 'believe'. ${ }^{45}$ Amyraut, like Calvin is quick both to emphasize the universal language and nature of God's heart and expression toward salvifically loving the whole world, while consistently qualifying God's universal intent and propitiation in Christ as effective (efficacious) only to those who conditionally believe on Christ. Yet, Amyraut consigns the meaning of these verses as proof of God's universal provision as it relates to the extent of the atonement stating, "thus, if you consider the care that God has taken to procure the salvation of the human race by sending his Son into the world and the things that he has done and suffered to this end, the grace is universal and presented to all men. ${ }^{46}$ Likewise, Calvin notes that when Jesus speaks of the world for whom He died in verse sixteen, he applies the term "indiscriminately to all ... all without exception". ${ }^{47}$

In Amyraut's Defense de la Doctrine de Calvin where he defends and corrects erroneous misperceptions and malconstruences of Calvin's theology, Amyraut quotes Calvin's commentary text on John 3:16 no less than seven times throughout the entire work. Amyraut understands Calvin to be teaching conditional salvation throughout this section, but especially presses the comment of Calvin on 3:17 that "no one is excluded from salvation provided that he holds to the way of salvation" ${ }^{48}$ In complete accordance with Calvin on this thought, Amyraut unequivocally states, "Thus, God wanted to render mercy to all, provided that all receive by faith this [gift] mercy". ${ }^{49}$

Appraising the biblical texts of 1 Timothy 2:4 and 4:5-6, Amyraut again speaks to a universal employment of God's intention and efficacious action in procuring atonement on behalf of all men and all sin. Amyraut, in close association with Calvin's original thoughts, notes, "This is to say that not only does God not exclude any, but that it would be very easy for all the world to approach him, in that $\mathrm{He}$ here invites the whole world as to a grace which he has destined for all the human

were allowed. Amyraut and his friends seem to be saying that a faulty a priori methodology had produced in orthodoxy a barrier to honest historico-exegetical research", Armstrong, 166.

John Calvin, "Commentary on the Gospel According to John", Calvin's Commentaries, vol. 17, trans. by W. Pringle (Grand Rapids: Baker, 2009), 120. Calvin continues: "The word 'world' comes again so that no one at all may think he is excluded, if only he keels to the road of faith... for God has ordained His Son to be the salvation of the world".

$48 \quad$ CO, 47:66 as cited in Armstrong, 202.

49 Amyraut, Defense, 106. 
race, if it is not shown to be unworthy" ${ }^{50}$ Amyraut concludes, "And this is why St. Paul calls it 'the grace of salvation to all men' (Titus 2:11)" ${ }^{51}$ Emphasizing that "universal" means universal, explicitly for all, as he cites Acts 10:34-35 and 13:46-47, Amyraut clarifies that "it is not necessary to think however that there is either any people or even a single man excluded by the will of God from the salvation that He has acquired for the human race, provided that man makes his use of the testimonies of mercy that God has given to him". ${ }^{52}$

Also in line with Calvin's concept that "we must understand that as long as Christ remains outside of us, and we are separated from him, all that he has suffered and done for the salvation of the human race remains useless and of no value for us", Amyraut insists that the verses of 1Timothy, though emphasizing God's universal design for the salvation of the world, also imply the necessary limitation (provision) that they believe. ${ }^{53}$ Amyraut contends, "If they do not believe, He does not desire it. This will to make the grace of salvation universal and common to all men is in this way conditional that without the accomplishing of the condition, is entirely ineffectual". ${ }^{54}$

Amyraut's teaching that the universal salvific will of God is limited by the condition "if they believe" and therefore ineffectual in itself, concomitantly agrees with Calvin's explanation of Ezekiel 33:11 and 2 Peter 3:9.

One point of variance between Amyraut's commentary on 1 Timothy 2:4 and Calvin's concerns the meaning of the terminology "all" men within that specific text. Unlike Calvin, Amyraut does interpret the "all" differently than Calvin in that he understands it to refer to all men as individuals, rather than to various classes of men. Yet, both Calvin and Amyraut render their interpretation for the same reason and meaning (contra Beza), namely that God has not differentiated between people who can be saved. In short, both Calvin and Amyraut hold that Scripture teaches that salvation is open to all men and as such is to be proclaimed to all men equally and universally for God's glory and men's salvation. For both Amyraut and Calvin,

Amyraut, Brief Treatise, 40. As Calvin connected 1 Timothy 2:4 with its extended Old Testament counterparts, Ezekiel 18:23, 33:11, in The Eternal Predestination of God, Amyraut quotes extensively from Calvin's explanation and insight against Pighius. Amyraut quotes Calvin: "God wills all to be saved. That He does not will the death of a sinner is to be believed on His own oath where He says by the prophet: As I live, I do not will the death of a sinner, but rather that he may be converted and live (Ezechiel 18:23; 33:11). But I contend that, as the prophet is exhorting to penitence, it is no wonder that He pronounces God willing that all be saved. So again with the promises which invite all men to salvation, they do not simply and positively declare what God has decreed in His secret counsel but what He is prepared to do for all who are brought to faith and repentance", John Calvin, Concerning the Eternal Predestination of God, trans. by J. K. S. Reid (London, 1961), 105-6.

$51 \quad$ Ibid., 40.

Ibid., 40.

Calvin, Institutes, 3.1.1.

Amyraut, Brief Treatise, 78.

PERICHORESIS 11.1 (2013) 
their determination of the text in this particular case renders their interpretation exactly the same, though having arrived at their same conclusion differently (syntactically). Amyraut concludes, reinforcing his main premise of universal atonement which he feels patently echoes Calvin's theological sentiments:

It offers to us only the benevolence of God who pays regard to all men universally in that He promises them salvation provided that they believe, and the commandment of God who again regards them equally, to receive by faith the Redeemer Whom He offers to them ... for the promise of salvation is equally and universally given to all who believe. ${ }^{55}$

In summation, unlike Beza, Amyraut's tone and theological insight appear to match very closely to Calvin's perspectives concerning the intention and efficacious nature of the atonement as expressed biblically through universal language. Though currently modern scholars contend for Calvin on both sides of the atonement debatea debate which will no doubt be a perennial discussion for the foreseeable futurein his time, Amyraut felt truly compelled to adduce Calvin into the universal atonement camp, based on Amyraut's intimate reading of textual proofs from Calvin's commentaries, sermons, and theological treatises. In this last section on Amyraut, comparing Amyraut and Calvin on the scriptural subject of the nature of the atonement has proven rather substantive in corroborating Amyraut's claims to hold a closer view of the atonement to Calvin than to Reformed orthodoxy, represented by Beza.

\section{Conclusion}

The aim of this paper has been to demonstrate that-using Calvin's words and theological insights concerning scriptural indications of the extent of the atonement as a control from which to compare Theodore Beza and Moïse Amyraut respectivelythere is sufficient evidence among textual comparisons to conclude that Amyraut appears closer to Calvin as it relates to the universal language of the atonement than does his successor Beza. Though this paper has not claimed that Amyraut is identical in soteriology with Calvin, the overt analysis with respect to both theologians' scriptural understanding, hermeneutic, and methodology underscore vivid similarities between Calvin and Amyraut's thoughts in terms of the extent of the atonement and the universal language of Scripture, where Beza's thoughts consistently demonstrate disparity with Calvin. Further, this paper has not contended that Calvin's only perspective concerning the extent of the atonement is that he lauds the universal language of Scripture over against other limited or particular concepts associated with Christ's atonement. On this matter, Richard Lum insightfully states, "until Calvin's own view is demonstrated conclusively, it is too much to claim that Amyraut's doctrine of the universal intention of the atonement represents any 
greater departure from Calvin than does the doctrine of limited atonement as taught in the Canons of Dort. ${ }^{56}$

Rather the result of this paper's analysis has been to validate Amyraut's claims that his theological perspective concerning the nature of the atonement is closer to Calvin than what transpired into the orthodox tradition under Beza's leadership. Though Amyraut contends that his theology is both specifically biblical, from a natural (unforced) reading of Scripture, and that his theology is coextensive with Calvin concerning the universal language and desire of God's provision in unselective expiation, not all are as convinced. Roger Nicole gives several reasons in his doctoral dissertation which charges Amyraut with overreaching his suppositions, summarizing that simple similarity between he and Calvin on a number of theological interpretations is not decisively conclusive that Calvin held to general atonement. However, for the purpose of this paper, it is significant that in comparing both Beza and Amyraut with Calvin on a number of scriptural texts and overarching soteriological themes, Amyraut makes a strong case for himself in that he published two lengthy volumes of theological self-comparisons between he and Calvin; further, Amyraut wrote extensively on behalf of erroneous accusations toward Calvin's theology with hopes of correcting inaccurate misperceptions of Calvin and demonstrating a like affinity towards Calvin's theology.

In essence, after having compared forthright biblical texts which speak to the apparent extent of the atonement, one can conclude that Amyraut is just in holding himself as a closer representation to Calvin's soteriological ideals on the subject of predestination and especially the extent of the atonement. Both Calvin and Amyraut boldly suggest that Christ's work on the Cross appears to be universal in its scope. Further, both theologians hold the scriptural command to share the gospel to all peoples indiscriminately speaks, in part, to the issue of God's divine intention towards the nature of the atonement. At the very least, this paper has demonstrated that Beza is not closer in interpretation and application of scripture when comparing he and Calvin on the texts which deal with the extent of the atonement in Scripture.

Holding that Beza took Calvin's arguments and theological framework further than where Calvin was comfortable going or speculating for himself, Beza's firm speculative stance necessitates a harsh philosophical-logical (scholastic) system that is at odds with Calvin's plain hermeneutic and subsequent interpretation of various texts dealing with the extent of the atonement. Though Calvin leaves room for mystery, tension, and undisclosed realities in the mind of God concerning special revelation, Beza pushes for concrete syncretisms in order to complete his deductivelogical soteriology, imagined in the divine decrees which necessitate a limited atonement and restricted intentionality in God's salvific plan. In the end analysis, Beza (and the subsequent Bezian orthodox Reformed theology) fall short of being able 
to claim best approximation of Calvin in terms of the nature of the atonement within selected biblical texts. Rather, Amyraut has demonstrated a consistent propensity to be both biblically relevant in his hermeneutic and application of Scripture towards the doctrine of predestination, while also being contiguous with Calvin's thoughts and application concerning Christ's universal intent and work on the Cross.

\section{Bibliography}

\section{Primary Sources}

Amyraut, Moïse. Brief Traitté de la Prédestination et Ses Principales Dépendances. Saumur: Lesnier \& Desbordes, 1634.

. Defense de la Doctrine de Calvin Sur le Sujet de l'Election and Réprobation. Saumur: Isaac Desbordes, 1644.

. Dissertationes Theologicae. Six volumes. Saumur: Desbordes, 1645.

. L'Eschantillon de la Doctrine de Calvin Touchant la Predestination. Saumur: Desbordes, 1658.

Beza, Theodore. A Briefe and Pithie Some of the Christian Faith Made in Forme of a Confession, with a Confutation of all Such Superstitious Errours, as Are Contrary Thereunto. Translated by Robert Fills. London: NP, 1563.

. Ad Acta Colloquii Montisbelgardensis Tubingae Edita Theodori Bezae Responsio Pars Altera. Geneva, 1588.

. A Booke of Christian Questions and Answers: Wherein are Set Forth the Chief Points

of the Christian Religion. Translated by Arthur Golding. London: W. How, 1574.

. Cours sur Les Epîtres aux Romains et aux Hebrieux 1564-66: d'Après Les Notes de

Marcus Widler. Edited by P. Fraenkel and L. Perrotet. Geneva: NP, 1988.

. Norum Testamentum, 1560 edition. New York: D. Appleton, 1861.

. Propositions and Principles of Divinity. Translated by Antoine de la Faye. Edin-

burg: Waldegraue, 1585.

. Quaestionum et Responsionum Christianarum Pars Altera: Quae Est de Sacramentis.

Geneva, 1576.

. Tractiones Theologicae. Three volumes. Geneva, 1570-1582.

Calvin, John. Calvin's Commentaries. Twenty one volumes. Translated by W. Pringle. Grand Rapids: Baker, 2009.

. Concerning the Eternal Predestination of God. Translated by J. K. S. Reid. London, 1961.

. Institutes of the Christian Religion. Edited by John T. McNeill. Translated by

Ford Lewis Battles. Two volumes. The Library of Christian Classics 20-21. Philadelphia: Westminster, 1960. Institutio Christianae Religionis. Volumes 3-5 of Joannis Calvini opera selecta. Edited by P. Barth and G. Niesel. Five volumes. Munich: Kaiser, 1926-36.

Sermons on Isaiah's Prophecy of the Death and Passion of Christ. Translated by T.

H. L. Parker. London: James Clarke \& Co., 2002.

PERICHORESIS 11.1 (2013) 


\section{Secondary Sources}

Armstrong, Brian G. Calvinism and the Amyraut Heresy. Madison: University of Wisconsin Press, 1969.

Barnes, Tom. Atonement Matters: A Call to Declare the Biblical View of the Atonement. Webster, N.Y: Evangelical Press, 2008.

Beilby, James and Paul R. Eddy, eds. The Nature of the Atonement: Four Views. Downers Grove: IVP, 2006.

Cottret, Bernard. "Calvin, Etait-Il Calviniste?” Bulletin Du Centre Protestant D'Etudes 7 (2009): 4-18.

Dever, Mark and Michael Lawrence, eds. It is Well: Expositions on Substitutionary Atonement. Wheaton: Crossway, 2010.

Douty, Norma, F. Did Christ Die Only for the Elect? A Treatise on the Extent of the Atonement. Eugene, OR: Wipf \& Stock Publishers, 1998.

Fluhrer, Gabriel, ed. Atonement. Phillipsburg, NJ: P. and R. Publishing, 2010.

Hill, Charles, E. and Frank A. James III, eds. The Glory of the Atonement: Biblical, Theological, and Practical Perspectives. Downers Grove, MI: IVP, 2004.

Kendall, R. T. Calvin and English Calvinism to 1649. UK: Paternoster Press, 1997.

Kennedy, Kevin. Union with Christ and the Extent of the Atonement. Bern: Peter Lang, 2002.

Kuiper, R. B. For Whom Did Christ Die? A Study of the Divine Design of the Atonement. Eugene, OR: Wipf \& Stock Publishers, 1993.

Kuiper, H. Calvin on Common Grace. Grand Rapids, MI: Baker, 1928.

Lightner, Robert Paul. The Death Christ Died. A Case for Unlimited Atonement. Des Plaines, Ill: Regular Baptist Press, 1967.

Long, Gary, D. Definite Atonement. Frederick, MD: New Covenant Media, 2006.

Moore, Jonathan. English Hypothetical Universalism. John Preston and the Softening of Reformed Theology. Grand Rapids, MI: Eerdmans, 2007.

Muller, Richard, A. After Calvin: Studies in the Development of a Theological Tradition. Oxford: Oxford University Press, 2003.

Murray, John. For Whom Did Christ Die? The Extent of the Atonement. Birmingham: Solid Ground Christian Books, 2010.

Packer, J. I. and Mark Dever. In My Place Condemned He Stood: Celebrating the Glory of the Atonement. Wheaton: Crossway, 2007.

Peterson, Robert, A. Calvin and the Atonement. Geanies House, Scotland: Mentor, 2009.

Stauffer, Richard. Moïse Amyraut: Un Précurseur Français De L'OEcuménisme. Paris: Cahors, 1962.

. The Quest for Church Unity: From John Calvin to Isaac d'Huisseau. Allison Park, PA: Pickwick Publications, 1986.

Thomas, Michael G. "The Extent of the Atonement: A Dilemma for Reformed Theology from Calvin to the Consensus (1536-1675)". Studies in Christian History and Thought. Eugene, OR: Wipf \& Stock Publishers, 2007. 
Van Stam, F. P. The Controversy over the Theology of Saumur (1635-1650): Disrupting the Debates Among Huguenots in Complicated Circumstances. Amsterdam: Holland University Press, 1988.

Vickers, Brian. Jesus' Blood and Righteousness: Paul's Theology of Imputation. Wheaton: Crossway, 2006.

\section{Periodicals}

Bell, M. Charles. "Calvin and the Extent of the Atonement". The Evangelical Quarterly 55 (1983): 115-123.

Cook, Peter. "Calvin and the Atonement". A Review in Evangelical Quarterly 74.3 (2002): 279.

De Lima, Leandro Antonio. "Calvino Ensinou a Expiação Limitada?” Fides Reformata 9.1 (2004): 77-99.

Gerrish, B. A. "Union with Christ and the Extent of the Atonement in Calvin". A Review in Theology Today 61.1 (2004): 142-144.

Gomes, Alan W. "Faustus Socinus and John Calvin on the Merits of Christ". Reformation E Renaissance Review: Journal of the Society for Reformation Studies 12.2-3 (2010): 189-205.

Gunton, Colin. "Aspects of Salvation: Some Unscholastic Themes from Calvin's Institutes”. International Journal of Systematic Theology 1.3 (1999): 253.

Kleinman, Ruth. "Calvinismus Und Franzosische Monarchie Im 17. Jahrhundert". American Historical Review 82.4 (1977): 977.

Macleod, Donald. “Amyraldus Redivivus: A Review Article”. Evangelical Quarterly 81.3 (2009): 210-229.

McGowan, A. T. B. "Amyraldianism. Is It Modified Calvinism?/ Amyraut Affirmed". Evangelical Quarterly 77.2 (2005): 186-187.

"Moïse Amyraut". 1-1: Columbia University Press, 2011.

Moore, Jonathan D. "Calvin versus the Calvinists? The Case of John Preston (15871628)". Reformation \& Renaissance Review: Journal of the Society for Reformation Studies 6.3 (2004): 327-348.

Placher, William C., John Flett, Michael Purcell, Lain Taylor, Andrew T. Lincoln, Paul M. Collins, W. Ross Hastings, and Nathan R. Strunk. "Reviews". International Journal of Systematic Theology 7.3 (2005): 316-342.

Rouwendal, P. L. "Calvin's Forgotten Classical Position on the Extent of the Atonement: About Sufficiency, Efficiency, and Anachronism”. Westminster Theological Journal (2008): 317-335.

Witt, Jared L. "Union with Christ and the Extent of the Atonement in Calvin". A Review in Renaissance Quarterly 58.2 (2005): 626-628.

Wright, Nigel G. "Predestination and Perseverance in the Early Theology of Jürgen Moltmann”. Evangelical Quarterly 83.4 (2011): 330-345. 


\section{Dissertations}

Archibald, Paul N. "A Comparative Study of John Calvin and Theodore Beza on the Doctrine of the Extent of the Atonement". PhD diss., Westminster Theological Seminary, 1998.

Berry, H. E. "The Amyraldian Controversy and its Implications for the LutheranReformed Unity in the Doctrine of Grace”. BD thesis, Concordia Theological Seminary, 1970.

Chambers, N. A. “A Critical Examination of John Owen's Argument for Limited Atonement in the Death of Death in the Death of Christ", ThM thesis, Reformed Theological Seminary, 1998.

Daniel, C. "Hyper-Calvinism and John Gill". PhD diss., University of Edinburgh, 1983.

Godfrey, W. R. "Tensions within International Calvinism: The Debate on the Atonement at the Synod of Dort, 1618-1619”. PhD diss., Stanford University, 1974.

Grohman, D. D. "The Genevan Reactions to the Saumur Doctrine of Hypothetical Universalism, 1635-1685”. ThD diss, Knox College in cooperation with Toronto School of Theology, 1971.

Harmon, Matthew Paul, "Moyse Amyraut's Six Sermons: Directions for Amyrauldian Studies”. ThM thesis, Westminster Theological Seminary, 2008.

Nicole, R". Moyse Amyraut (1596-1664) and the Controversy on Universal Grace: First Phase (1634-1637)". PhD diss., Harvard University, 1966.

Nomura, S. "The Extent of the Atonement in Calvin's Concept of the Preaching of the Gospel". ThM thesis, Western Theological Seminary, 1991.

Proctor, L. "The Theology of Moïse Amyraut Considered as a Reaction Against Seventeenth-Century Calvinism”. PhD diss., University of Leeds, 1952.

Shultz, Gary L. "A Biblical and Theological Defense of a Multi-Intentioned View of the Atonement". PhD diss., Southern Baptist Theological Seminary, 2008.

Wenkel, David, “John Bunyan's Theory of Atonement in His Early Doctrinal and Polemic Works Amyraldian or Particular?” MA thesis, Trinity Evangelical Divinity School, 2004. 